\title{
Depressive Symptoms, Loss of Appetite and Under Nutrition among Treated HIV Patients: A Cross Sectional Study in Goma, the Democratic Republic of Congo
}

\author{
Pierre Zalagile Akilimali ${ }^{*}$, Patou Masika Musumari², Pierrot LundimuTugirimana ${ }^{3}$, Paulin Beya \\ Mutombo $^{1}$, Frederick J Veldman ${ }^{4}$, Patrick Kalambayi Kayembe ${ }^{5}$, Mapatano Mala Ali ${ }^{1}$, Thorkild \\ Tylleskar ${ }^{6}$, Esperance Kashala-Abotnes ${ }^{6}$ \\ ${ }^{1}$ University of Kinshasa, School of Public Health, Department of Nutrition Democratic Republic of Congo \\ ${ }^{2}$ Kyoto University School of Public Health, Department of Global Health and Socio-Epidemiology, Kyoto, Japan \\ ${ }^{3}$ Faculty of Medicine, University of Goma, Goma, Democratic Republic of the Congo \\ ${ }^{4}$ KwaZulu-Natal University, Dietetic and Human Nutrition, Pietermaritzburg, South Africa \\ ${ }^{5}$ University of Kinshasa, School of Public Health, Department of Epidemiology and Biostatistics, Democratic Republic of Congo \\ ${ }^{6}$ University of Bergen, Centre for International Health, Norway
}

Received: May 18, 2016; Accepted: June 07, 2016; Published: June 24, 2016

*Corresponding author: Pierre Zalagile Akilimali, University of Kinshasa, School of Public Health, Department of Nutrition Democratic Republic of Congo, Tel: +243-815-800-288; E-mail: pierretulanefp@gmail.com

\begin{abstract}
Background: The study explored the association between the depressive symptoms, loss of appetite and under nutrition among treated HIV patients in Goma, a post conflict setting.

Methodology: This was a cross-sectional survey carried out from February $1^{\text {st }}$ to March $3^{\text {rd }}, 2016$. The prevalence of depressive symptoms and loss of appetite were estimated. A logistic regression model was used to identify the associations between under nutrition, loss of appetite and depressive symptoms, adjusted for other covariates.

Results: The proportion of participants with depressive symptoms was $21.3 \%$ (95\% CI: $17.1-25.5)$. The prevalence of loss of appetite was 50.1\% (95\% CI: 45 - 55\%). Depressive symptoms (AOR 2.19; 95\%CI: 1.27 - 3.79), smoking (AOR: 2.97; 95\%CI: 1.03 - 8.58) and low socio-economic status (AOR: 1.74; 95\%CI: $1.05-2.88$ ) were associated with loss of appetite. Loss of appetite (AOR: 3.29; 95\% CI: $1.92-5.64$ ) and receiving efavirenz (AOR: 2.13 ; 95\% CI: $1.24-3.66$ ) were significantly associated with under nutrition.

Conclusion: The fact that about one-fifth hand half of the sample reported having respectively depressive symptoms and the lack of appetite demonstrates the magnitude of the problems. There is a need for longitudinal studies to elucidate the pathways linking depressive symptoms, appetite and under nutrition.
\end{abstract}

Keywords: Depressive Symptoms; Loss of Appetite; Under Nutrition; HIV; Antiretroviral

\section{Introduction}

High prevalence of malnutrition and food insecurity are often linked to conflict situations [1], which can affect the mental well-being of vulnerable population and put them at higher risk for mental problems, such as depression or anxiety[2]. HIV patients, because of their circumstances, are at increased risk of depression [3], food insecurity, and malnutrition [4], and even more so in a post-conflict area.

Malnutrition, and more specific under nutrition, is generally associated with increased mortality among HIV infected individuals initiating Anti Retroviral Therapy (ART) $[5,6]$. The etiology of HIV-associated under nutrition is multi factorial. Indeed, weight loss is a major symptom of AIDS before starting ART several mechanisms need to be explored, such as poor appetite [7].

Depression is common among HIV patients [8] and remains important clinically because untreated or sub-optimally treated depression may result in worsened HIV-related outcomes [9, 10]. Depression is a critical element in HIV care as it has been associated with steeper declines in CD4 counts [11], greater risk of developing HIV-dementia [12], worse antiretroviral medication adherence [13], and more rapid progression to AIDS and death $[11,12]$.

Although antiretroviral therapy (ART) can suppress human immune deficiency virus (HIV) replication and decrease morbidity and mortality in HIV-positive individuals, it has, however, numerous adverse drug reactions (ADR). Efavirenz (EFV) is one of the molecules included as a first-line drug in combination with other ART, in the DRC [14]. More than 50\% of patients who take EFV have experienced neuropsychiatric ADR $[15,16]$ and depression following EFV therapy has been reported in $2 \%$ of patients [17].

Depression has been linked to decreased appetite, therefore 
there is a need to understand whether loss of appetite and depressive symptoms impact nutrition of HIV patients receiving ART in the DR Congo. A study among older people living in nursing homes showed that patients with depression ran twice the risk of having poor appetite compared to those not affected [18]. Appetite is a complex phenomenon that contributes to an individual's body weight. Loss of appetite may vary due to psychobiological changes and environmental factors [19]. The phenomenon becomes more complicated in cases of chronic illness. Because of the clinical importance of both depression and loss of appetite to HIV outcomes, and because of the elevated prevalence of both factors among HIV patients in conflict setting, there is a need for increased attention to issues of reverse causality and potential confounding.

The study particularly explored the impact of depressive symptoms and loss of appetite on the under nutrition among HIV patients on ART in Goma, a post conflict setting. We further hypothesize that depressive symptoms are related to under nutrition mainly in persons with loss of appetite among HIV under ARTMethodology

\section{Study design, participants and setting}

This Goma multicenter cross-sectional study was carried out from February $1^{\text {st }}$ to March $3^{\text {rd }}, 2016$. Goma, the capital city of the North Kivu province had an estimated population of 725,000 in 2015 [20] and an HIV prevalence in the adult population of 0.9\% [21]. The city has experienced armed conflict since 1996 and there are still areas where the conflict has not yet come to an end. In Goma in 2015, 10 health centers were providing HIV care and treatment services [20], providing ART for a total of 3,586 patients aged 15 years and above. This survey included patients from five of these centers: Heal Africa Hospital (512 patients), Virunga Hospital (812 patients), the Charity Hospital (132 patients), General Military Hospital (77 patients) and Goma Provincial Referral Hospital (1,099 patients) [20]. None of these facilities provided food or any kind of nutrition support to patients. All of the hospitals had been providing HIV care for more than one year at the time of the study.

Participants were included in the study provided that they were at least 18 years old, on ART for at least 6 months, and had given written informed consent. Participants were interviewed during their routine visits to the treatment center from February $1^{\text {st }}$ to March $3^{\text {rd }}, 2016$. The questionnaire was translated into French and Swahili and piloted in a sample of 20 respondents (not included in the final analysis). The interviews were conducted in French or Swahili, the most commonly used languages in Goma. The interviewers were provided guidance on questionnaire administration over two training sessions, which were organized by the research team. Participants were compensated for their time and transportation with an amount of 2 US dollars.

\section{Sample size determination}

This sample size was calculated to correctly assess the proportion of HIV-infected individuals with depressive symptoms, of $18.8 \%$ [22]. The power calculation used the Kish-
Leslie formula, with a $5 \%$ level of precision, a confidence interval (CI) of $95 \%$. The minimal required sample size was 235 . We added $10 \%$ for contingency and a total of 367 patients were invited to participate in the study.

\section{Measures}

Primary outcome: The primary outcome of interest was the nutritional status, which was assessed using Body Mass Index (BMI) as a proxy. Participant height and weight were measured. A BMI (weight $(\mathrm{kg}) /[\text { height }(\mathrm{m})]^{2}$ ) of $<18.5$ was classified as under nutrition. The outcome was expressed as prevalence (\%) of under nutrition among treated HIV patients.

Primary independent variables: Depressive symptoms and loss of appetite

The Simplified Nutritional Appetite Questionnaire (SNAQ) was used to assess the loss of appetite and loss of weight within six months [23]. A SNAQ score of $\leq 14$ indicates poor appetite and significant risk of at least $5 \%$ weight loss within six months. This score had good internal reliability with a Cronbach alpha of 0.80 .

To measure depressive symptoms, we used the 10-item Hopkins Symptom Checklist for depression (HSCL-10) [24]. HSCL is a prime candidate as a valid clinical instrument for identifying depression in the primary health care [25], and in research [26, 27]. It has been used in the similar context in Uganda [28].

In the present study, respondents were asked whether they were bothered by each symptom on a 4-point scale from "not at all" (0) to "extremely" (3). The HSCL-10 score was calculated by dividing the total score by 10 (number of items). A score equal or above 1.6 was considered as indicative of the presence of depressive symptoms in the present study [24]. The internal consistency of this measure was good in this sample, with a Cronbach's alpha of 0.84 .

\section{other covariates}

The other covariates included adherence, food insecurity, regimen (including EFV or not) and socio-demographic characteristics such as age, gender, educational level, marital status, residence, household size, and household wealth index.

Adherence to medication was based on patient self-reports. Patients were asked to quantify the number of days during which they failed to take their medicines over the previous 7 days. Selfreported non- adherence was defined as taking $<95 \%$ of the prescribed drugs over this period of time [29].

Food insecurity was measured by the Household Food Insecurity Access Scale (HFIAS) developed by the USAID-funded Food And Nutrition Technical Assistance (FANTA) project [30]. The HFIAS is a validated instrument and has been shown to distinguish food insecure from food secure households across different cultural contexts. It is a set of nine questions designed to reflect universal domains of the experience of food insecurity including 1) anxiety and uncertainty about the household food supply, 2) insufficient quality (includes variety and preferences of the type of food), and 3) insufficient food intake and its 
physical consequences. We calculated results in a categorical format including 1) food secure, 2) mildly food insecure 3) moderately food insecure, and 4) severely food insecure, which we dichotomized into food insecure versus food secure. The Cronbach's alpha was 0.89 , demonstrating a good internal consistency of the scale in our sample.

The household index was constructed based on the method proposed by Filmer and Prichett [31]. The method relies on principal component analysis to create an index from a set of household assets (radio, tape recorder, television set, bicycle, hand torch, horse or donkey cart), housing conditions (roof material, number of rooms, wall type, windows, availability and type of latrine), and ownership of domestic animals. The study participants were ranked according to the wealth index score, divided into quintiles, from the lowest (first quintile) to the highest (fifth quintile). Higher quintiles indicate higher socioeconomic status. In the analysis we presented SES in three levels: low (lowest and lower quintile), middle (middle quintile) and High (Higher and highest quintile).

\section{Statistical analysis}

Data were analyzed using Stata 12 . Univariate analysis was conducted to obtain descriptive statistics of all the variables. Mean and standard deviation of age and BMI, and proportions and their respective $95 \%$ confidence intervals for categorical data, were calculated.

Bivariate analyses were performed using Chi-square tests for categorical variables and the t-test for age and BMI. The bivariate correlation coefficient was calculated. Factors associated with loss of appetite and under nutrition by bivariate analysis with $\mathrm{p}$ value $\leq 0.10$ were entered into a respective logistic regression model to obtain Adjusted Odds Ratios (AOR) and their 95\% confidence intervals $(95 \% \mathrm{CI})$. An interaction term was introduced between loss of appetite and smoking in the under nutrition model to assess the presence of effect modification. The Breslow-day test was used for assessing the interaction effect. Significance level was set at $\mathrm{p}<0.05$.

\section{Ethical review}

This study was conducted in accordance with the Declaration of Helsinki and all procedures involving human subjects/ patients were approved by the ethics committee for research at the Kinshasa University, School of Public Health (No App: ESP/ CE/128/15 of 22.12.2015). Written and verbal informed consent were obtained from all patients. Verbal consent was witnessed and formally recorded. Subjects were also explained their right to withdraw at any point of the study.

\section{Results}

\section{Characteristics of patients}

Of the 369 participants, $76.7 \%$ were women Table 1 . The mean age was 43.4 years (Standard Deviation [SD] 10.7). Only $16 \%$ of the patients had completed at least secondary school. A third of the patients were widowed. Half of the patients had shared their HIV status and their treatment with others (sexual partners or others family member). At the time of the study, 350 (95\%) were living in households with food insecurity and 5\% were smokers. Only $21 \%$ of the patients had been on ART for less than a year, and $42 \%$ had been on ART for more than 5 years. Fifteen per cent of the patients had a pretreatment CD 4 cell count under 200 cells $/ \mathrm{ml}$. One hundred and five (29\%) patients were on three-drug regimens containing EFV. Twenty-six percent were underweight (with $\mathrm{BMI}<18.5 \mathrm{~kg} / \mathrm{m}^{2}$ ). Eighty-three percent of the patients were adherent to ART (95\% CI: 79.1 - 86.9).

\section{Depressive Symptoms (HSCL-10 score)}

The proportion of participants with depressive symptoms was $21.3 \%$ (95\% CI: 17.1 - 25.5). We did not find a significant difference between patients receiving EFV or not in terms of depressive symptoms ( 25.7 vs. $19.5 ; \mathrm{p}=0.186$ ). There was no significant difference in depressive symptoms between those having a pretreatment CD4 cell count under 200 cells $/ \mathrm{ml}$ or not (38.5\% vs. $24.3 \%$; $p=0.065$ ). There was a significant difference in depressive symptoms between those living in households with food insecurity vs. those living in households with food security $(22.4 \%$ vs. $0 \% ; p=0.020)$ Table 2 . The correlate coefficient between food insecurity and depressive symptoms was 0.121 $(\mathrm{p}=0.020)$

\section{Loss of appetite}

This study showed that 182 of the patients (50.1\%: 95\% CI: $45-55$ ) had a poor appetite, i.e., SNAQ scores < 14, with a risk of developing future weight loss. We found that depression (2.17; 95\%CI: 1.11 - 4.22), smoking (2.97; 95\%CI: 1.03 - 8.58) and low socio-economic status $(1.77 ; 95 \% \mathrm{CI}: 1.07-2.92)$ were associated with loss of appetite Table 3.

\section{Factors associated with under nutrition}

The overall prevalence of under nutrition (BMI $<18.5 \mathrm{~kg} /$ $\mathrm{m}^{2}$ ) was $26.2 \%$ (95\% CI: $21.7 \%$ - 30.7\%). The logistic regression showed that loss of appetite (AOR: 3.29; 95\% CI: $1.92-5.64$ ) and receiving EFV (AOR: 2.13; 95\% CI: 1.24 - 3.66) were significantly associated with under nutrition Table 4.

\section{Discussion}

This study found that one-fifth of HIV patients on ART had depressive symptoms and a high prevalence of loss of appetite (50.1\%).This study has revealed a strong association between depressive symptoms and the loss of appetite. Furthermore, loss of appetite was associated with under nutrition.

The prevalence of depressive symptoms estimated in this study is almost similar to what has been reported previously using the same tool $[22,32]$, though lower than reported in other HIV primary care sites that reported prevalences above $20 \%$ [33, 34]. The scales for screening depressive symptoms used in these studies did not exclude somatic measures, and probably may have therefore overestimated the prevalence of depressive symptoms. There were an overlap between symptoms of depression and symptoms of HIV infection $[35,36]$ in these estimates.

While depression may lead to poor ART uptake, it is also 
Table 1: Background characteristics of study participants.

\begin{tabular}{|c|c|c|c|c|}
\hline \multirow[t]{2}{*}{ Characteristics } & \multirow[t]{2}{*}{ Overall* } & \multicolumn{2}{|c|}{ Gender } & \multirow[t]{2}{*}{$\mathbf{p}$} \\
\hline & & male & female & \\
\hline Age, mean \pm SD (years) & $43.36 \pm 10.68$ & $48.44 \pm 10.11$ & $41.81 \pm 10.37$ & $<0.001$ \\
\hline $\begin{array}{c}\text { Age }^{* *} \\
-\quad>\text { median } \\
-\quad \leq \text { median }\end{array}$ & $\begin{array}{l}170(46.1) \\
199(53.9)\end{array}$ & $\begin{array}{l}58(67.4) \\
28(32.6)\end{array}$ & $\begin{array}{l}112(39.6) \\
171(60.4)\end{array}$ & $<0.001$ \\
\hline $\begin{array}{ll}\text { Education level attained } \\
- & \text { None/ primary } \\
- & \text { Secondary or higher }\end{array}$ & $\begin{array}{c}309(84.0) \\
59(16.0)\end{array}$ & $\begin{array}{l}57(66.3) \\
29(33.7)\end{array}$ & $\begin{array}{c}252(89.4) \\
30(10.6)\end{array}$ & $<0.001$ \\
\hline $\begin{array}{ll}\text { Marital status } \\
-\quad & \text { Widow(ed) } \\
- & \text { Other }\end{array}$ & $\begin{array}{l}120(32.6) \\
248(67.4)\end{array}$ & $\begin{array}{c}6(7.1) \\
79(92.9)\end{array}$ & $\begin{array}{l}169(59.7) \\
114(40.3)\end{array}$ & $<0.001$ \\
\hline $\begin{array}{l}\text { Household size } \\
-\quad>6 \text { members } \\
-\quad \leq 6 \text { members }\end{array}$ & $\begin{array}{l}175(47.9) \\
190(52.1)\end{array}$ & $\begin{array}{l}36(41.9) \\
50(58.1)\end{array}$ & $\begin{array}{l}154(55.2) \\
125(44.8)\end{array}$ & 0.030 \\
\hline 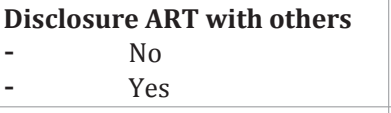 & $\begin{array}{l}177(49.9) \\
178(50.1)\end{array}$ & $\begin{array}{l}58(69.0) \\
26(31.0)\end{array}$ & $\begin{array}{l}119(43.9) \\
152(56.1)\end{array}$ & $<0.001$ \\
\hline $\begin{array}{ll}\text { Alcohol } & \\
- & \text { Yes } \\
- & \text { No }\end{array}$ & $\begin{array}{l}135(36.6) \\
234(63.4)\end{array}$ & $\begin{array}{l}37(43.0) \\
49(57.0)\end{array}$ & $\begin{array}{c}98(34.6) \\
185(65.4)\end{array}$ & 0.157 \\
\hline $\begin{array}{ll}\text { Smoking } \\
- & \text { Yes } \\
- & \text { No }\end{array}$ & $\begin{array}{c}20(5.4) \\
349(94.6)\end{array}$ & $\begin{array}{l}16(18.6) \\
70(81.4)\end{array}$ & $\begin{array}{c}4(1.4) \\
279(98.6)\end{array}$ & $<0.001$ \\
\hline $\begin{array}{ll}\text { SES*** }^{* *} & \\
- & \text { Low } \\
- & \text { Middle } \\
- & \text { Higher } \\
\end{array}$ & $\begin{array}{c}175(47.4) \\
64(17.3) \\
130(35.2)\end{array}$ & $\begin{array}{l}32(37.2) \\
13(15.1) \\
41(47.7)\end{array}$ & $\begin{array}{l}143(50.5) \\
51(18.0) \\
89(31.4)\end{array}$ & 0.021 \\
\hline \begin{tabular}{ll}
\multicolumn{2}{l}{ Residence } \\
- & At Goma \\
- & Outside Goma
\end{tabular} & $\begin{array}{c}346(94.3) \\
21(5.7)\end{array}$ & $\begin{array}{c}82(95.3) \\
4(4.7)\end{array}$ & $\begin{array}{c}264(94.0) \\
17(6.0)\end{array}$ & 0.625 \\
\hline $\begin{array}{ll}\text { Duration on ART } \\
- & 5 \text { years and }+ \\
- & 1-4.9 \text { years } \\
- & <1 \text { year }\end{array}$ & $\begin{array}{l}152(41.9) \\
136(37.5) \\
75(20.7)\end{array}$ & $\begin{array}{l}36(41.9) \\
33(38.4) \\
17(19.8)\end{array}$ & $\begin{array}{l}116(41.9) \\
103(37.2) \\
58(20.9)\end{array}$ & 0.966 \\
\hline 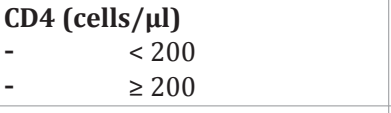 & $\begin{array}{c}39(15.4) \\
215(84.6)\end{array}$ & $\begin{array}{c}6(10.5) \\
51(89.5)\end{array}$ & $\begin{array}{c}33(16.8) \\
164(83.2)\end{array}$ & 0.251 \\
\hline $\begin{array}{l}\text { Adherence to ART } \\
-\quad \text { Yes } \\
-\quad \text { No }\end{array}$ & $\begin{array}{c}303(83.0) \\
62(17.0)\end{array}$ & $\begin{array}{l}73(84.9) \\
13(15.1)\end{array}$ & $\begin{array}{c}230(82.4) \\
49(17.6)\end{array}$ & 0.597 \\
\hline $\begin{array}{l}\text { ART Regimen } \\
-\quad \text { including EFV } \\
-\quad \text { without EFV }\end{array}$ & $\begin{array}{l}105(28.5) \\
264(71.5)\end{array}$ & $\begin{array}{l}22(25.6) \\
64(74.4)\end{array}$ & $\begin{array}{c}83(29.3) \\
200(70.7)\end{array}$ & 0.500 \\
\hline 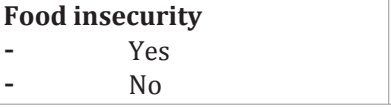 & $\begin{array}{c}350(94.9) \\
19(5.1)\end{array}$ & $\begin{array}{c}80(93.0) \\
6(7.0)\end{array}$ & $\begin{array}{c}270(95.4) \\
13(4.6)\end{array}$ & 0.381 \\
\hline
\end{tabular}

Table 2: Depressive symptoms and respondent characteristics.

\begin{tabular}{|c|c|c|c|}
\hline \multirow[t]{2}{*}{ Characteristics* } & \multicolumn{2}{|c|}{ Depression } & \multirow[t]{2}{*}{$\mathbf{p}$} \\
\hline & Yes & No & \\
\hline Age, mean $\pm \mathrm{SD}($ years $)$ & $42.24 \pm 10.82$ & $43.71 \pm 10.65$ & 0.284 \\
\hline $\begin{array}{ll}\text { Age }^{* *} & \\
- & >\text { median } \\
- & \leq \text { median }\end{array}$ & $\begin{array}{l}32(18.8) \\
46(23.4)\end{array}$ & $\begin{array}{l}138(81.2) \\
151(76.6)\end{array}$ & 0.291 \\
\hline
\end{tabular}

Citation: Akilimali PZ, Musumari PM, Tugirimana PL, Mutombo PB, Veldman FJ, et al. (2016) Depressive Symptoms, Loss of Appetite and Under Nutrition among Treated HIV Patients: A Cross Sectional Study in Goma, the Democratic Republic of Congo. J Nutrition Health Food Sci 4(2): 1-10. DOI: http://dx.doi.org/10.15226/jnhfs.2015.00162 
Depressive Symptoms, Loss of Appetite and Under Nutrition among Treated HIV Patients: A Cross Sectional Study in Goma, the Democratic Republic of Congo

\begin{tabular}{|c|c|c|c|}
\hline $\begin{array}{ll}\text { Gender } & \\
- & \text { Male } \\
- & \text { Female }\end{array}$ & $\begin{array}{l}15(17.4) \\
63(22.4)\end{array}$ & $\begin{array}{c}71(82.6) \\
218(77.6)\end{array}$ & 0.323 \\
\hline $\begin{array}{ll}\text { Education level attained } \\
- & \text { None/ primary } \\
- & \text { Secondary or higher }\end{array}$ & $\begin{array}{c}70(22.7) \\
7(12.7)\end{array}$ & $\begin{array}{l}238(77.3) \\
51(87.9)\end{array}$ & 0.068 \\
\hline \begin{tabular}{ll}
\multicolumn{2}{l}{ Marital status } \\
- & Widowed \\
- & Others
\end{tabular} & $\begin{array}{l}30(25.0) \\
48(19.5)\end{array}$ & $\begin{array}{c}90(75.0) \\
198(80.5)\end{array}$ & 0.229 \\
\hline $\begin{array}{l}\text { Household size } \\
-\quad>6 \text { members } \\
-\quad \leq 6 \text { members }\end{array}$ & $\begin{array}{l}36(20.7) \\
41(21.7)\end{array}$ & $\begin{array}{l}138(79.3) \\
148(78.3)\end{array}$ & 0.815 \\
\hline 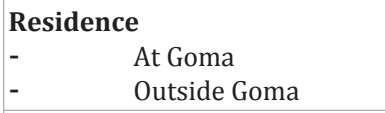 & $\begin{array}{c}74(21.4) \\
4(20.0)\end{array}$ & $\begin{array}{c}271(78.6) \\
16(80.0)\end{array}$ & 0.878 \\
\hline 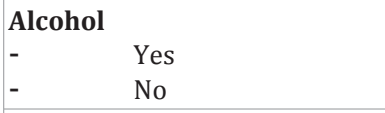 & $\begin{array}{l}28(20.7) \\
50(21.6)\end{array}$ & $\begin{array}{l}107(79.3) \\
182(78.4)\end{array}$ & 0.855 \\
\hline $\begin{array}{ll}\text { Smoking } & \\
- & \text { Yes } \\
- & \text { No }\end{array}$ & $\begin{array}{c}5(25.0) \\
73(21.0)\end{array}$ & $\begin{array}{c}15(75.0) \\
274(79.0)\end{array}$ & 0.674 \\
\hline $\begin{array}{l}\text { Disclosure ART with others } \\
- \\
-\end{array}$ & $\begin{array}{l}42(23.6) \\
34(19.4)\end{array}$ & $\begin{array}{l}136(76.4) \\
141(80.6)\end{array}$ & 0.341 \\
\hline $\begin{array}{ll}\text { SES*** }^{* *} & \\
- & \text { Low } \\
- & \text { Middle } \\
- & \text { Higher } \\
\end{array}$ & $\begin{array}{l}42(24.1) \\
16(25.0) \\
20(15.5)\end{array}$ & $\begin{array}{c}132(75.9) \\
48(75.0) \\
109(84.5)\end{array}$ & 0.139 \\
\hline $\begin{array}{ll}\text { Duration on ART } \\
- & 5 \text { years and }+ \\
- & 1-4.9 \text { years } \\
- & <1 \text { year }\end{array}$ & $\begin{array}{l}32(21.1) \\
30(22.2) \\
15(20.0)\end{array}$ & $\begin{array}{l}120(78.9) \\
105(77.8) \\
60(80.0)\end{array}$ & 0.685 \\
\hline \begin{tabular}{lc}
\multicolumn{2}{l}{ Food insecurity } \\
- & Yes \\
- & No
\end{tabular} & $\begin{array}{c}78(22.4) \\
0(0.0)\end{array}$ & $\begin{array}{l}299(85.9) \\
19(100.0)\end{array}$ & 0.020 \\
\hline $\begin{array}{lr}\text { CD4 (cells/ } / \boldsymbol{\mu l}) \\
-\quad<200 \\
-\quad \geq 200\end{array}$ & $\begin{array}{l}15(38.5) \\
52(24.3)\end{array}$ & $\begin{array}{c}24(61.5) \\
162(75.7)\end{array}$ & 0.065 \\
\hline \begin{tabular}{lc}
\multicolumn{2}{l}{ Adherence to ART } \\
- & Yes \\
- & No
\end{tabular} & $\begin{array}{l}63(20.9) \\
13(21.0)\end{array}$ & $\begin{array}{c}238(79.1) \\
49(79.0)\end{array}$ & 0.995 \\
\hline \begin{tabular}{ll}
\multicolumn{2}{|l}{ Regimen } \\
- & Including EFV \\
- & Without EFV
\end{tabular} & $\begin{array}{l}27(25.7) \\
51(19.5)\end{array}$ & $\begin{array}{c}78(74.3) \\
211(80.5)\end{array}$ & 0.186 \\
\hline overall & $78(21.3)$ & $289(78.7)$ & \\
\hline
\end{tabular}

Table 3: Associated factors with loss of appetite among HIV infected patients receiving ART in five Hospitals of Goma in 2016.

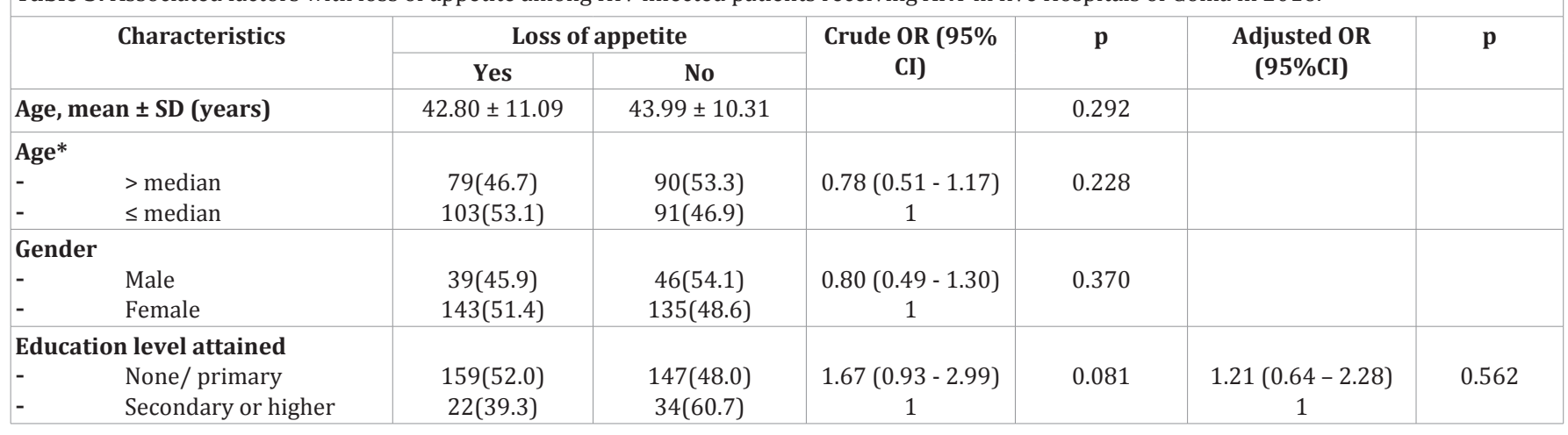

Citation: Akilimali PZ, Musumari PM, Tugirimana PL, Mutombo PB, Veldman FJ, et al. (2016) Depressive Symptoms, Loss of Appetite and Under Nutrition among Treated HIV Patients: A Cross Sectional Study in Goma, the Democratic Republic of Congo. J Nutrition Health Food Sci 4(2): 1-10. DOI: http://dx.doi.org/10.15226/jnhfs.2015.00162 
Depressive Symptoms, Loss of Appetite and Under Nutrition among Treated HIV Patients: A Cross Sectional Study in Goma, the Democratic Republic of Congo

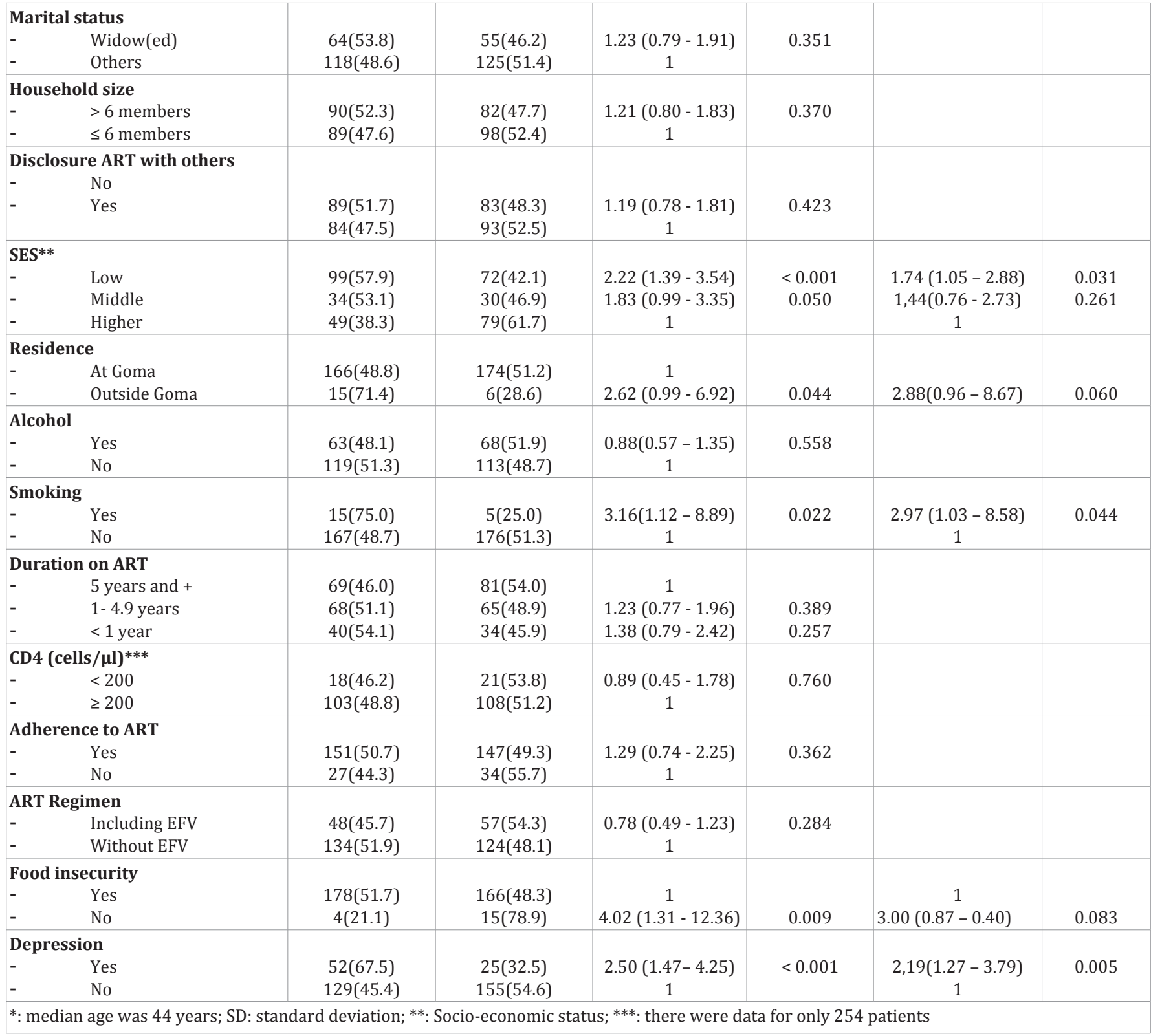

Table 4: Associated factors with undernutrition among HIV infected patients receiving ART in five Hospitals of Goma in 2016.

\begin{tabular}{|c|c|c|c|c|c|c|c|}
\hline & \multirow[t]{2}{*}{ Characteristics } & \multicolumn{2}{|c|}{ Under nutrition } & \multirow[t]{2}{*}{ Crude OR (95\% CI) } & \multirow[t]{2}{*}{$\mathbf{p}$} & \multirow{2}{*}{$\begin{array}{l}\text { Adjusted OR } \\
\text { (95\%CI) }\end{array}$} & \multirow[t]{2}{*}{$\mathbf{p}$} \\
\hline & & Yes & No & & & & \\
\hline $\begin{array}{l}\text { A } \\
- \\
-\end{array}$ & $\begin{array}{l}>\text { median } \\
\leq \text { median }\end{array}$ & $\begin{array}{l}38(22.6) \\
58(29.3)\end{array}$ & $\begin{array}{l}130(77.4) \\
140(70.7)\end{array}$ & $\begin{array}{c}0.71(0.44-1.13) \\
1\end{array}$ & 0.148 & & \\
\hline $\begin{array}{l}\text { Gr } \\
- \\
-\end{array}$ & $\begin{array}{l}\text { male } \\
\text { female }\end{array}$ & $\begin{array}{l}21(24.7) \\
75(26.7)\end{array}$ & $\begin{array}{c}64(75.3) \\
206(73.3)\end{array}$ & $\begin{array}{c}0.90(0.51-1.58) \\
1\end{array}$ & 0.716 & & \\
\hline $\begin{array}{l}\text { Ec } \\
-\end{array}$ & $\begin{array}{l}\text { on level attained } \\
\text { None/ primary } \\
\text { Secondary or higher }\end{array}$ & $\begin{array}{l}79(25.7) \\
17(29.3)\end{array}$ & $\begin{array}{c}228(74.3) \\
41(70.7)\end{array}$ & $\begin{array}{c}0.84(0.45-1.55) \\
1\end{array}$ & 0.570 & & \\
\hline $\begin{array}{l}\text { M } \\
- \\
-\end{array}$ & $\begin{array}{l}\text { status } \\
\text { Widow(ed) } \\
\text { Others }\end{array}$ & $\begin{array}{l}33(27.7) \\
63(25.5)\end{array}$ & $\begin{array}{c}86(72.3) \\
184(74.5)\end{array}$ & $\begin{array}{c}1.12(0.68-1.84) \\
1\end{array}$ & 0.651 & & \\
\hline
\end{tabular}




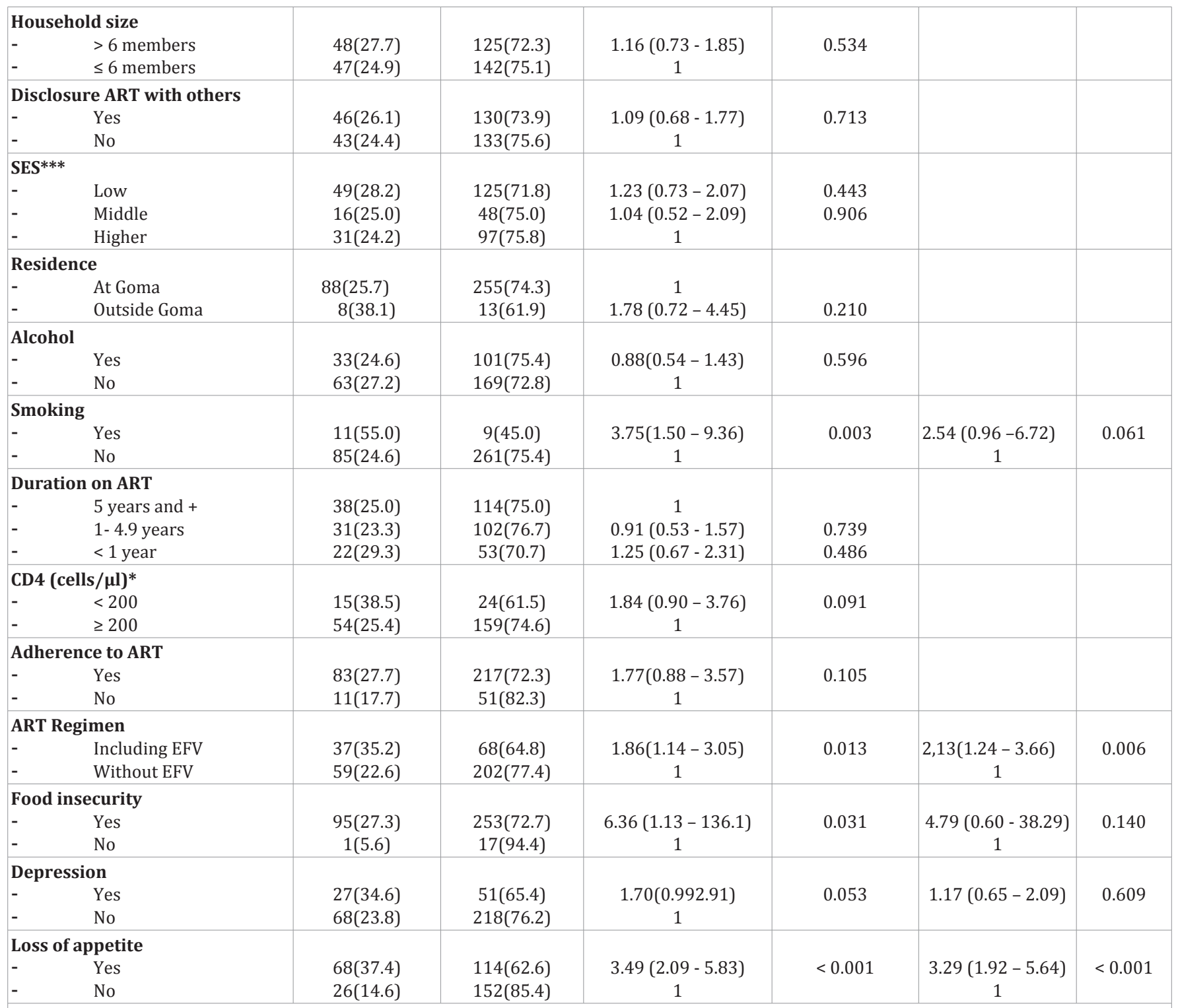

*: with available data; **: median age was 44 years; SD: standard deviation; ***: Socio-economic status; There was not interaction between Loss of appetite and smoking (Breslow-day test, $\mathrm{p}=0.706$ ).

possible that limited access to ART could lead to depression in resource-limited settings [37]. Nevertheless, the prevalence reported in the present study remains high. It can be due to other factors such as the post conflict context in Goma.

Half of the patients reported a loss of appetite, which puts them at risk of weight loss. The prevalence of loss of appetite in this study was similar to which reported among patients with kidney disease [38], but, lower than what has been observed in patients with other chronic conditions, for example cancer (88\%) [39]. Symptoms of depression, smoking and low socio economic status were associated with loss of appetite. Symptoms of depression are suitable for interventions. These findings correspond with other studies that have demonstrated that depressive symptoms constitute a barrier for nutrition intake $[40,41]$. As depression can be a barrier for performing adequate nutritional self-care activities, health care professionals could routinely screen for and treat depressive symptoms among HIV patients under ART [42]. Smoking was significantly associated with loss of appetite in multivariate analysis. Smoking is known to reduce taste perception and appetite $[43,44]$. Moreover, smoking may increase the feeling of fullness when consuming a hot evening meal, thereby lowering energy intake [45]. In addition, smoking is known to increase resting energy expenditure, which could lead to higher energy needs [46]. Those metabolic effects of smoking could explain the loss of appetite levels and put the smokers at risk of weight loss. However, some drugs may also suppress the appetite or cause side effects that put you off food, such as nausea, vomiting, indigestion or altered taste but we did not assess this aspect in this study.

Under nutrition was associated with loss of appetite and 
regimen containing EFV. Previous research showed that loss of appetite is an independent factor associated with under nutrition $[47,48]$. A poor appetite can cause a lower nutritional intake [49] and thereby increases the risk of under nutrition [50]. As loss of appetite is associated with under nutrition and worsened prognosis [51, 52], these findings need to be addressed in the care of HIV patients on ART. In particular, Screening for poor appetite could potentially decrease underweight in HIV clinics.

We also found that people who received EFV reported to be more undernourished. But we did not find association between EFV and depression, while previous studies reported associations between EFV and depressives symptoms $[15,17]$. EFV is one of the molecules of choice as the first-line drug, in combination with other ART for treatment of HIV infection according to DR Congo policy [14]. Researchers, policy makers and health professionals should find solutions helping HIV patients to better benefit from EFV treatment taking into consideration possible depressive symptoms among patients.

The link between BMI and depressive symptoms is inconsistent in the literature. The failure to show statistical association between depressive symptoms and under nutrition may be due to the relatively small sample size. However, the causality between the state of nutrition and the appearance of symptoms of depressions is ambiguous because we do not have explicit evidence whether the undernourishment actually stands behind the depression, or whether perhaps the state of nutrition leads to depressive disorders [53].

In order to prevent under nutrition, particularly in HIV infected patients, health care professionals should routinely assess and discuss appetite in HIV infected care. Discussions about appetite and dietary habits with patients and family members may serve for individualized nutrition advice and interventions.

\section{Limitations}

This study has limitations that need to be considered. Most importantly, the study had a cross-sectional design, which limits the possibilities to draw any causal conclusions regarding the relationship between the identified factors and loss of appetite. This highlights the need for further prospective studies, for example trajectories of appetite over time and associated factors. In this study, we did not assess other causes of loss of appetite such as opportunistic disease especially those affecting mouth (candidiasis...) and others intestinal problems (such as diarrhea and constipation). There are different methods to assess depressive symptoms, using HSCL-10 for assessing depressive symptoms excluded the overlap between symptoms of depression and symptoms of HIV infection [35, 36] and can estimate the prevalence with less bias in this study. The other advantage by using HSCL-10 is the fact it has been used in a similar setting [28] and in DR Congo [54] and the internal consistency of this measure was good in this sample, with a Cronbach alpha of 0.84 . However, even if questionnaire was translated in both language French and Swahili, we cannot excluded totally bias during interview.

Concerning appetite, we used SNAQ scale for assessing appetite, which even if have shown good measurement properties [23]. This scale has not previously been validated in DR Congo. However, this resulted in difficulties comparing the finding with other studies. Appetite is not a variable likely to generate more socially desirable responding. However, response bias related to respondent cannot be excluded. Another limitation was the small number of assessments to determine nutritional status, as BMI cannot, alone, fully assess nutritional status.

Even if we have used a multivariate technique, there can be two causes of residual confounding in this study. Firstly, there were probably the additional confounding factors that were not considered, because data on these factors was not collected. Secondly, there could be residual confounding in the noncompliance regression analysis because age was simply classified as " $\leq 44$ years" or "> 44 years". There could occur during data collection the errors in the classification of subjects with respect to confounding variables. Some people in Africa does not know exactly their age. These aspects can introduce a misclassification

\section{Conclusion}

The fact that about one-fifth and half of the sample reported having respectively depressive symptoms and the lack of appetite demonstrates the magnitude of the problems. Depressive symptoms and the loss of appetite are associated and loss of appetite is associated with under nutrition in HIV patients on ART. There is a need for longitudinal studies to elucidate the pathways linking Depressive symptoms, appetite and under nutrition.

\section{Acknowledgments}

We are grateful to the Virunga Hospital, Charity Hospital, Heal Africa Hospital, General Military Hospital and Referral Goma Provincial Hospital Staff. This research was supported by Grow Nut Project (Growing Partnership for Higher Education and Research in Nutritional Epidemiology in DR Congo), Project number: QZA-0484, COG-13/0002).

\section{Authors' contributions}

PZA designed the research, drafted the research protocol and the data collection tools then managed the data and conducted the statistical analysis. EKA, TT and MMA contributed to the revision of the protocol to the final version. PZA and PLT conducted the research. TT, PMM, PLT, FJV, EKA, PKK and MMA provided oversight and input into all aspects of the study. PZA, PMM, EKA, PBM, PLT, FJV, TT and MMA drafted the manuscript. All authors contributed to the review and editing of the manuscript to the final version.PZA and EKA had primary responsibility for the final content. All authors read and approved the final version of the manuscript.

\section{References}

1. Food and Agriculture Organization of the United Nations (FAO). Child nutrition and food security during armed conflicts. Rome, Italy. 2010.

2. Kinyanda E, Waswa L, Baisley K, Maher D. Prevalence of severe mental distress and its correlates in a population-based study in rural south-west Uganda. BMC Psychiatry. 2011;11:97. doi:10.1186/1471- 


\section{X-11-97.}

3. Valente S. M. Depression and HIV disease. Journal of the Association of Nurses in AIDS Care. 2003;14(2):41-51.

4. Benzekri NA, Sambou J, Diaw B, Sall el HI, Sall F, Niang A, et al. High Prevalence of Severe Food Insecurity and Malnutrition among HIVInfected Adults in Senegal, West Africa. PLoS ONE. 2015;10(11): e0141819.

5. Argemi X, Dara S, You S, Mattei JF, Courpotin C, Simon B, et al. Impact of malnutrition and social determinants on survival of HIV-infected adults starting antiretroviral therapy in resource-limited settings. Aids. 2012;26(9):1161-1166. doi:10.1097/QAD.0b013e328353f363.

6. Ivers LC, Cullen KA, Freedberg KA, Block S, Coates J, Webb P. HIV/AIDS, Under nutrition and Food Insecurity. Clinical infectious diseases : an official publication of the Infectious Diseases Society of America. 2009 ;49(7):1096-1102. doi:10.1086/605573.

7. Pilgrim A, Robinson S, Sayer AA, Roberts, H. An overview of appetite decline in older people. Nursing Older People. 2015;27(5):29-35. doi:10.7748nop.27.5.29.e697

8. Bing EG, Burnam MA, Longshore D, Fleishman JA, Sherbourne CD London AS, et al. Psychiatric disorders and drug use among human immunodeficiency virus-infected adults in the United States. Archives of General Psychiatry. 2001;58(8):721-728.

9. Anastos K, Schneider MF, Gange SJ, Minkoff H, Greenblatt RM, Feldman J, et al. The association of race, sociodemographic, and behavioral characteristics with response to highly active antiretroviral therapy in women. Journal of Acquired Immune Deficiency Syndromes. 2005;39(5):537-544.

10. Carrico AW, Bangsberg DR, Weiser SD, Chartier M, Dilworth SE, Riley ED. Psychiatric correlates of HAART utilization and viral load among HIV-positive impoverished persons. AIDS. 2011;25(8):1113-1118. doi:10.1097/QAD.0b013e3283463f09

11. Burack JH, Barrett DC, Stall RD, Chesney MA, Ekstrand ML, Coates TJ. Depressive symptoms and CD4 lymphocyte decline among HIVinfected men. JAMA. 1993;270:2568-2573.

12. Farinpour R, Miller EN, Satz P, Selnes OA, Cohen BA, Becker JT, et al Psychosocial risk factors of HIV morbidity and mortality: findings from the Multicenter AIDS Cohort Study (MACS). J ClinExpNeuropsychol. 2003;25: 654-670.

13. Holzemer WL, Corless IB, Nokes KM, Turner JG, Brown MA, PowellCope GM, et al. Predictors of self-reported adherence in persons living with HIV disease. AIDS Patient Care STDS. 1999;13:185-197.

14. DRC. Programme National de Lutte contre le VIH/SIDA et les ISTs. Guide national de prise en charge de l'infection à VIH en RDC. Juillet 2013

15. Blanch J, Martinez E, Rousaud A, Blanco JL, García-Viejo MA, Peri JM, et al. Preliminary data of a prospective study on neuropsychiatric side effects after initiation of efavirenz. J Acquir Immune DeficSyndr. 2001;27:336-43

16. Gutie'rrez-Valencia A, Viciana P, Palacio R Ruiz-Valderas R, Lozano F, Terrón A, et al . Stepped-dose versus full-dose efavirenz for HIV infection and neuropsychiatric adverse events, a randomized trial. Ann Intern Med. 2009;151:149-56

17. Bernard EJ. Does efavirenz cause depression? Aids treatment update. 2006;158:3

18. Landi F, Lattanzio F, Dell'Aquila G, Eusebi P, Gasperini B, Liperoti R, et al. Prevalence and potentially reversible factors associated with anorexia among older nursing home residents: results from the ULISSE project. Journal of the American Medical Directors Association. 2013;14(2):119-124. doi:10.1016/j.jamda.2012.10.022.

19. Muscaritoli M, Aversa Z, Laviano A, Fanelli FR, Anker SD, Argiles J, et al. Consensus definition of sarcopenia, cachexia and precachexia: Joint document elaborated by Special Interest Groups (SIG) cachexiaanorexia in chronic wasting diseases and nutrition in geriatrics. Clinical Nutrition. 2010;29:154-159. doi:10.1016/j.clnu.2009.12.004.

20. Programme National de Lutte contre le VIH/SIDA et les ISTs. Coordination provinciale du Nord Kivu. Rapport annuel 2015. 2016(Unpublished results)

21. Ministry of Planning. Demographic and health 2013-2014. Democratic Republic of Congo. Kinshasa. 2014.

22. Priscilla Martinez, Irene Andia, NnekaEmenyonu, Judith A. Hahn, EdvardHauff, Larry Pepper, et al. Alcohol Use, Depressive Symptoms and the Receipt of Antiretroviral Therapy in Southwest Uganda. AIDS Behav. 2008;12(4): 605-612. doi:10.1007/s10461-007-9312-x

23. Wilson MM, Thomas DR, Rubenstein LZ, Chibnall JT, Anderson S, Baxi A, et al. Appetite assessment: simple appetite questionnaire predicts weight loss in community-dwelling adults and nursing home residents. Am J Clin Nutr. 2005;82:1074-1081.

24. Haavet OR, Sirpal MK, Haugen W, Christensen KS. Diagnosis of depressed young people in primary health care-a validation of HSCL10. Family Practice.2011;28(2): 233-237. doi:10.1093/fampra/ cmq078.

25. Haavet OR, Christensen KS, Sirpal MK, Haugen W. Diagnosis of depression among adolescents - a clinical validation study of key questions and questionnaire. BMC Family Practice. 2007;8:41.

26. Hale WW $3^{\text {rd }}$, Raaijmakers QA, Muris P, van Hoof A, Meeus WH. One factor or two parallel processes? Comorbidity and development of adolescent anxiety and depressive disorder symptoms. Journal of Child Psychology and Psychiatry. 2009;50:1218-1226. doi:10.1111/ j.1469-7610.2009.02115.x.

27.Sagatun A, Lien L, Søgaard AJ, Bjertness E, Heyerdahl S. Ethnic Norwegian and ethnic minority adolescents in Oslo, Norway. A longitudinal study comparing changes in mental health. Soc Psychiatry Psychiatr Epidemiol. 2008;43(2):87-95.

28. Tsai AC, Bangsberg DR, Frongillo EA, Hunt PW, Muzoora C, Martin JN, et al. Food Insecurity, Depression and the Modifying Role of Social Support among People Living with HIV/AIDS in Rural Uganda. Social Science \& Medicine. 2012;74(12):2012-2019. doi:10.1016/j. socscimed.2012.02.033

29. Paterson DL, Swindells S, Mohr J, Brester M, Vergis EN, Squier C, et al. Adherence to protease inhibitor therapy and outcomes in patients with HIV infection. Ann Intern Med. 2000;133:21-30.

30. Coates J, Swindale A, Bilinsky P. Household Food Insecurity Access scale (HFIAS) for Measurement of Food Access: Indicator guide Washington, DC: Food and Nutrition Technical Assistance Project. Academy for Educational Development. 2007

31. Filmer Deon, Pritchett H Lant. Estimating wealth effects without expenditure data or tears: an application to educational enrollments in states of India. Demography. 2001;38(1):115-132.

32. Poupard M, Ngom Gueye N, Thiam D, Ndiaye B, Girard P, Delaporte E, et al. Quality of life and depression among HIV-infected patients receiving efavirenz- or protease inhibitor-based therapy in Senegal. HIV Medicine. 2007;8(2):92-95. doi: 10.1111/j.14681293.2007.00435.x 
33. Olley BO, Gxamza F, Seedat S, Theron H, Taljaard J, Reid E, et al Psychopathology and coping in recently diagnosed HIV/AIDS patients-the role of gender. South African Medical Journal. 2003;93(12):928-931.

34. Gupta R, Dandu M, Packel L, Rutherford G, Leiter K, Phaladze N, et al. Depression and HIV in Botswana: A Population-Based Study on Gender-Specific Socioeconomic and Behavioral Correlates. PLoS ONE 2010;5(12):e14252. doi: 10.1371/journal.pone.0014252.

35. Kaharuza FM, Bunnell R, Moss S, Purcell DW, Bikaako-Kajura W, Wamai N, et al. Depression and CD4 cell count among persons with HIV infection in Uganda. AIDS \& Behavior. 2006;10(4 Suppl):S105-111.

36. Kalichman SC, Sikkema KJ, Somlai A. Assessing persons with human immunodeficiency virus (HIV) infection using the Beck Depression Inventory: disease processes and other potential confounds. Journal of Personality Assessment. 1995;64(1):86-100.

37. Martinez P, Andia I, Emenyonu N, Hahn JA, Hauff E, Pepper L, et al Alcohol Use, Depressive Symptoms and the Receipt of Antiretroviral Therapy in Southwest Uganda. AIDS and Behavior. 2008;12(4):605612

38. Gama-Axelsson T, Lindholm B, Bárány P, Heimbürger O, Stenvinkel P \& Qureshi A. Self-rated appetite as a predictor of mortality in patients with stage 5 chronic kidney disease. Journal of Renal Nutrition. 2013;23(2):106-113. doi: 10.1053/j.jrn.2012.04.009

39. Liu Y, Zhang PY, Na J, Ma C, Huo WL, Han L, et al. Prevalence, intensity, and prognostic significance of common symptoms in terminally ill cancer patients. Journal of Palliative Medicine. 2013;16(7):752757. doi: $10.1089 /$ jpm.2013.0028

40. Lennie TA, Moser DK, Heo S, Chung ML \& Zambroski CH. Factors influencing food intake in patients with heart failure: a comparison with healthy elders. Journal of Cardiovascular Nursing. 2006;21(2):123-129.

41. Lesman-Leegte I, Jaarsma T, Sanderman R, Linssen G \& van Veldhuisen DJ. Depressive symptoms are prominent among elderly hospitalised heart failure patients. European Journal of Heart Failure. 2006;8(6):634-640.

42. Lainscak M, Blue L, Clark AL, Dahlstrom U, Dickstein K, Ekman I, et al. Self-care management of heart failure: practical recommendations from the Patient Care Committee of the Heart Failure Association of the European Society of Cardiology. European Journal of Heart Failure .2011;13(2):115-126. doi: 10.1093/eurjhf/hfq219.

43. Cochrane WJ \& Afolabi OA. Investigation into the nutritional status, dietary intake and smoking habits of patients with chronic obstructive pulmonary disease. J Hum Nutr Diet. 2004;17(1):3-11.

44.Vennemann MM, Hummel T \& Berger K. The association between smoking and smell and taste impairment in the general population. J Neurol. 2008;255(8):1121-1126. doi: 10.1007/s00415-008-0807-9.

45. Gregersen NT, Moller BK, Raben A, Kristensen ST, Holm L, Flint A, et al. Determinants of appetite ratings: the role of age, gender, BMI, physical activity, smoking habits, and diet/weight concern. Food Nutr Res. 2011;55. doi: 10.3402/fnr.v55i0.7028.

46. Blauw LL, Boon MR, Rosendaal FR, de Mutsert R, Gast KB, van Dijk $\mathrm{KW}$, et al. Smoking is associated with increased resting energy expenditure in the general population: the NEO study. Metabolism. 2015;64(11):1548-1555. doi: 10.1016/j.metabol.2015.08.008.

47. van der Pols-Vijlbrief, R, Wijnhoven HA, Schaap LA, Terwee CB, Visser $M$. Determinants of protein-energy malnutrition in communitydwelling older adults: a systematic review of observational studies. Ageing Res Rev. 2014;18:112-131. doi: 10.1016/j.arr.2014.09.001

48. Schilp J, Wijnhoven HA, Deeg DJ, Visser M. Early determinants for the development of undernutrition in an older general population: Longitudinal Aging Study Amsterdam. Br J Nutr. 2011;106(5):708717. doi: $10.1017 /$ S0007114511000717

49. Payette H, Gray-Donald K, Cyr R, V Boutier. Predictors of dietary intake in a functionally dependent elderly population in the community. Am J Public Health. 1995;85(5):677-683.

50. Margetts BM, Thompson RL, Elia M, Jackson AA. Prevalence of risk of undernutrition is associated with poor health status in older people in the UK. Eur J Clin Nutr. 2003;57(1):69-74.

51. Landi F, Lattanzio F, Dell'Aquila G, Eusebi P, Gasperini B, Liperoti R, et al. Prevalence and potentially reversible factors associated with anorexia among older nursing home residents: results from the ULISSE project. Journal of the American Medical Directors Association. 2013;14(2):119-124. doi: 10.1016/j.jamda.2012.10.022

52. Malafarina V, Uriz-Otano F, Gil-Guerrero L and Iniesta R. The anorexia of ageing: physiopathology, prevalence, associated comorbidity and mortality. A systematic review. Maturitas. 2013;74(4):293-302. doi: 10.1016/j.maturitas.2013.01.016.

53. Yoshimura K, Yamada M, Kajiwara Y, Nishiguchi S, Aoyama T. Relationship between depression and risk of malnutrition among community-dwelling young-old and old-old elderly people. Aging Ment Health. 2013;17(4):456-460. doi: 10.1080/13607863.2012.743961

54. Murray SM, Robinette KL, Bolton P, Cetinoglu T, Murray LK, Annan J, et al. Stigma Among Survivors of Sexual Violence in Congo: Scale Development and Psychometrics. J Interpers Violence. 2015; pii: 0886260515608805 . 